\title{
Factors Persuading the Intention of Using E-recruitment by Job Seekers in Bangladesh
}

\author{
[SK. Tasthekur Hossain Kowshik, Samia Shabnaz, Stanley Sumon Rodrick, Hamidul Islam]
}

\begin{abstract}
-with the cutting edge technological advancement globally, e-recruitment has gained importance for the employers and the job seeker. As Bangladesh have unacceptably high unemployment rate, studying the factors that influences the use of e-recruitment by the job seeker's would help developing effective unconventional Human resource management practices. A questionnaire was designed to examine applicant's intention to use e-recruitment by obtaining their opinions. Non-probability purposive sampling technique was used to select the sample. The data was collected from 250 job seekers who are graduates of different discipline from Dhaka city. This is an empirical study which used factor analysis and cross tabulation analysis to identify the factors and to recognize the relationship of different demographic factors like gender, education, internet experience, job areas with intention to use e-recruitment. The analysis identified the significant factors which swayed the intention of the job seeker's to use e-recruitment. The study will help the employer to concentrate on the factors which is considered important for the job seekers to make the e-recruitment process more effective and efficient.
\end{abstract}

\section{Keywords-e-recruitment, factors, Job seeker, Bangladesh}

\section{Introduction}

E-Recruitment is the method of recruiting personnel with the use of technology and web-based resources. The improvement of technologies made the recruitment process simpler for HR managers to believe on Internet along with the recruitment agencies. E-recruiting progressions rise competitive advantage through increased productivity and lower costs and offers benefits as well as opportunities to jobseekers (The Australian HR Institute, 2017).

Samia Shabnaz

American International University- Bangladesh Bangladesh

SK. Tasthekur Hossain Kowshik

American International University- Bangladesh Bangladesh

Stanley Sumon Rodrick

American International University- Bangladesh Bangladesh

Hamidul Islam

American International University- Bangladesh Bangladesh
Bangladesh is not an old member in this e-recruitment adoption process for this reason there are many areas where the employers must concentrate to make the full use of this technological changes. One of the bright parts of internet includes the e-recruiting. In Bangladesh at the beginning the e-recruitment system was mostly appreciated by the private sector but now days with the motto (Digital Bangladesh) of the Bangladesh government the public sectors are also adopting the e-recruitment system.

The use of e-recruiting has direct impact on both the organizations as well as jobseekers who apply this technique in the hiring as well as job search process. Particularly, Jobseekers use e-recruitment for some key factors those including increasing scope of getting job, lowering the job searching costs, secured system, both way communications, getting more information regarding the organization, easy to understand the applying process.

The main objective of this study is to find out job seekers' level of awareness, knowledge and application of using e-recruitment as a tool to search their relevant job placements as well as differentiate the application procedures that the applicants apply through the erecruitment procedures in comparison with the traditional approaches. This study also concentrated on identifying the possible problems that the applicants encounter while applying for the job placements through the e-recruitment platform.

\section{Literature Review}

Old-style recruitment has always considered as a time consuming and paper intensive process. Online recruitment agencies or sights are looking to eliminate the pains associated with finding the right person or job. Attractive to both active and passive job seekers, recruitment web sites save companies as well as job hunters both time and money. Old methods of recruitment processes are readily recognized as being time consuming with high costs and limited geographic reach. However, recruitment through World Wide Web (WWW) provides global coverage and ease (Ahlawat, 2016).

Recruitment through internet is prevailing very slowly in Bangladesh, because maximum number of people still believe in seeking job through newspaper. Though the number of internet users are high but people like to use internet for specific purpose only (Karim, Miah and Khatun, 2015)

Despite of having innovative and interesting way of recruitment for job seekers, most of the people refer newspaper for searching jobs because old tradition of reading newspaper is still dominating in most of the developing country (Pavon \& Brown, 2010) 
Job-seekers are finding many favorable reasons to use online recruiting including scope, costs, security, sometime interactive relation with employers, information and simplifying the entire processing internet (Karim, Miah and Khatun, 2015).

Socio-demographic characteristics have significant influence in online recruitment which has been found through the study (Alsultanny and Alotaibi, 2015). Where gender and occupation have the influence, but age does not find any of the correlation.

Organizations choose their method of recruitment from their sociological perspective. They focus on the negative side of the process also. They are less likely to think about the positive aspect and usefullness of the recruitment process (Parry \& Wilson, 2009)

\section{Methodology}

The survey was conducted by using purposive sampling method since the sampling frame was unavailable. All questions were closed-ended where respondents were asked to tick according to their perception of online recruitment in various parameters. Before distributing the questionnaire, a pilot study was conducted and the questions were modified accordingly. In this study 250 questionnaires were distributed amongst which 234 were considered usable for analysis. The questionnaires were distributed to the job seekers who have done their graduation in different discipline. The survey covered numerous areas of Dhaka city namely Gulshan, Mothijheel, Mirpur, Banani and Bashundhara. Data entry and analysis was done with the statistical software SPSS version 20. Descriptive statistics were used to examine the demographic profile of customers, Cronbach's alpha to measure reliability and factor analysis to identify significant factors that influence the use of erecruitment.

\section{Discussion}

\section{1) Reliability Test}

As the questionnaire used for data collection was designed rather than adopted from an existing research, a reliability test was thought necessary. The Cronbach Alpha testing was used as it is the most well accepted reliability test tools applied by social researcher (Sekaran, 2003). The closer Cronbach's Alpha is to 1.0, the higher is the internal consistency reliability. Cronbach measures indicates that if the reliability is more than 0.8 than it is considered to be good. The questionnaire used in this research is considered acceptable as its value mentioned in Table I are more than 0.80 .

TABLE I. RELIABILITY STATISTICS

\begin{tabular}{|l|l|}
\hline Cronbach's Alpha & N of Items \\
\hline .912 & 24 \\
\hline
\end{tabular}

The demographic profile of the respondent is given in the table II below. Here it can be seen that more than half of the respondents $(64.1 \%)$ are male and rest is female $(35.9 \%)$. Top respondents age is between 25 and $29(42 \%)$ It is indicated that a large number of respondents $(70.1 \%)$ are employed. Most of the respondents (70.9\%) are using internet for more than 5 years .Most of the respondents no $(26.1 \%)$ or $1-2(31.6 \%)$ years of job experience. Most of the job seekers $(52.1 \%)$ are finding mid-level job. Majority of the respondent $(67.9 \%)$ said that the respondent rate from the employer is very low. Finally most of the respondent (62\%) said they use Bangladeshi job portal to apply for job.

TABLE II. DEMOGRAPHIC PROFILE

\begin{tabular}{|c|c|c|}
\hline \multirow[b]{2}{*}{ Gender } & Male & $64.1 \%$ \\
\hline & Female & $35.9 \%$ \\
\hline \multirow{4}{*}{ Age } & $20-24$ & $29.5 \%$ \\
\hline & $25-29$ & $42.3 \%$ \\
\hline & $30-34$ & $15 \%$ \\
\hline & $34+$ & 13.2 \\
\hline \multirow[b]{2}{*}{ Employement Status } & Unemployed & $29.9 \%$ \\
\hline & Employed & $70.1 \%$ \\
\hline \multirow{4}{*}{ Years of Internet use } & Less than 2 years & $6 \%$ \\
\hline & $2-3$ years & $4.7 \%$ \\
\hline & $4-5$ years & $18.4 \%$ \\
\hline & $5+$ years & 70.9 \\
\hline \multirow{4}{*}{ Job experience } & No experience & $26.1 \%$ \\
\hline & $1-2$ years & $31.6 \%$ \\
\hline & 3-4 years & $15.4 \%$ \\
\hline & $4+$ years & $26.9 \%$ \\
\hline \multirow{3}{*}{ Job seeking level } & Entry & $39.3 \%$ \\
\hline & Middle & $52.1 \%$ \\
\hline & Top & $8.5 \%$ \\
\hline \multirow{5}{*}{$\begin{array}{l}\text { Problems of online job } \\
\text { search }\end{array}$} & Response rate is low & $67.9 \%$ \\
\hline & Time consuming & $10.3 \%$ \\
\hline & Costly & $0.4 \%$ \\
\hline & Trust issue & $15.4 \%$ \\
\hline & Internet connectivity & $6 \%$ \\
\hline \multirow{4}{*}{ Online media used } & Bdjobs/prothom Alo Jobs & $62 \%$ \\
\hline & Facebook group/pages & $16.2 \%$ \\
\hline & Linkedin & $11.5 \%$ \\
\hline & Company Website & $10.3 \%$ \\
\hline
\end{tabular}

Barlett's test of sphericity is a test statistic used to examine the hypothesis that the variables are uncorrelated in the population (Malhotra, 2008, p. 642). In other words, the test provides the statistical probability that the correlation matrix has significant correlation among at least some of the variables. On doing the KMO test it is observed that the value is 0.915 which is greater than 0.5 the significance level is 0.000 which indicates that the KMO value is significant. Hence, the factor analysis is appropriate. Also, the hypothesis that the correlation matrix is an identity matrix can be rejected, i.e., the correlation matrix has significant correlations among at least some of the variables.

TABLE III. KMO AND BARTLETT'S TEST

\begin{tabular}{|l|l|l|}
\hline Kaiser-Meyer-Olkin Measure of Sampling Adequacy. & .913 \\
\hline \multirow{3}{*}{ Bartlett's Test of Sphericity } & Approx. Chi-Square & 2705.0099 \\
\cline { 2 - 3 } & df & 276 \\
\cline { 2 - 3 } & Sig. & .000 \\
\hline
\end{tabular}

In the communities table it is observed that all the variables explains more than $50 \%$ of the variation. The question that explained most about online recruitment was the question related to Intention to use e-recruitment for vacancy search $(73.9 \%)$ and the lowest was the trust with professional information while online recruitment (49.6\%). In the next table using the Principal Component Analysis 
Proc. of the Eighth International Conference On Advances in Economics, Management and Social Study - EMS 2018 Copyright (C) Institute of Research Engineers and Doctors. All rights reserved.

ISBN no.978-1-63248-146-7 doi: 10.15224/ 978-1-63248-146-7-16

method the factors have been extracted. All those factors, whose Eigen values were greater than 1.0, were considered.

\section{TABLE IV. COMMUNALITIES}

\begin{tabular}{|l|l|l|}
\hline E-recruitment is the fastest mode to apply for jobs. & 1.000 & .650 \\
\hline $\begin{array}{l}\text { Applying for the jobs online is cost saving activity for } \\
\text { the prospective employees. }\end{array}$ & 1.000 & .551 \\
\hline $\begin{array}{l}\text { Applying through job portal and social network site is } \\
\text { more accessible to the candidate. }\end{array}$ & 1.000 & .545 \\
\hline $\begin{array}{l}\text { Online recruitment site can be trusted with professional } \\
\text { information. }\end{array}$ & 1.000 & .496 \\
\hline $\begin{array}{l}\text { Possession of essential resources to support to access the } \\
\text { internet. }\end{array}$ & 1.000 & .678 \\
\hline Capability to use the e-recruitment. & 1.000 & .739 \\
\hline It is easy to complete e-application. & 1.000 & .636 \\
\hline Using e- recruitment sites was easy & 1.000 & .646 \\
\hline $\begin{array}{l}\text { Interacting with online application process was clear and } \\
\text { understandable E-recruitment sites and their application } \\
\text { process did not require a lot of mental effort. }\end{array}$ & 1.000 & .585 \\
\hline It was easy to become skillful using e- recruitment sites. & 1.000 & .563 \\
\hline $\begin{array}{l}\text { The e-recruitment sites provide all the information } \\
\text { required to apply for a job. }\end{array}$ & 1.000 & .707 \\
\hline The e-recruitment sites provide information such as faqs. & 1.000 & .714 \\
\hline The e-recruitment sites provide feedback service. & 1.000 & .661 \\
\hline $\begin{array}{l}\text { Using e-recruitment sites enable me to compare between } \\
\text { different vacancies in my country and other countries. }\end{array}$ & 1.000 & .592 \\
\hline Using e-recruitment sites are interesting. & 1.000 & .664 \\
\hline $\begin{array}{l}\text { The actual process of using e- recruitment sites is } \\
\text { pleasant. }\end{array}$ & 1.000 & .602 \\
\hline $\begin{array}{l}\text { Positive attitude towards using e- recruitment } \\
\text { technology. }\end{array}$ & 1.000 & .679 \\
\hline Recommend e- technology to my friends. & 1.000 & .662 \\
\hline $\begin{array}{l}\text { Compared with the traditional recruitment e-recruitment } \\
\text { technology is better. }\end{array}$ & 1.000 & .668 \\
\hline E-recruitment use for job search is high. & 1.000 & .600 \\
\hline Willing to use e-recruitment for vacancy search. & 1.000 & .660 \\
\hline $\begin{array}{l}\text { Intention to use e-recruitment for vacancy search in } \\
\text { future. }\end{array}$ & 1.000 & .715 \\
\hline Trouble in the internet connection & 1.000 & .715 \\
\hline Saves time to submit resume & 1.000 & .561 \\
\hline
\end{tabular}

It is seen that five factors were extracted which accounted for $63.71 \%$ of the total variance. It can be observed that the first factor itself explains $38.10 \%$ of the variance. This indicates that the first factor highly influences intention of job seekers to use e-recruitment in Bangladesh. The 2nd, 3rd 4th and 5th factor explains $8.340 \%, 6.463 \%$, $5.814 \%$ and $4.994 \%$ of the variances respectively.

The table VI, explains the rotated component matrix using the varimax rotation method. Varimax rotation is orthogonal rotation in which assumption is that there are no inter-correlations between components. On completing the rotation in 7 iterations using the Principal Component Analysis, it is observed that all variables have factor loading of 0.49 or greater.

After rotation that was converged in 7 iterations, we find grouping in five factors. The first factor which explains $38.10 \%$ of the total variation, can be named attitude toward e-recruitment. Included in this factor are nine variables namely positive attitude towards using e-recruitment technology(Factor loading .784); recommend e-technology to my friends (Factor loading .767); Compared with the traditional recruitment e-recruitment technology is better (Factor loading .754); Intention to use e-recruitment for vacancy search in future (Factor loading .737), Willing to use e-recruitment for vacancy search.(Factor loading .716) E-recruitment use for job search is high. (Factor loading
.661), Using e-recruitment sites are interesting (Factor loading .648) The actual process of using e- recruitment sites is pleasant (Factor loading .627) and Saves time to submit resume (Factor loading .522). It is seen that all variable in this factor have loading values greater than 52\% which means these variables are satisfactory to explain the first factor. The second factor that explains $8.380 \%$ of the total variation related to satisfaction can be named as usefulness as these variables define the effectiveness of the content (e.g., The e-recruitment sites provide information such as FAQs, feedback, required information to apply, easy to complete application, ease of use, content clarity and understandability, skillfulness). Moreover all the variables have high factor loading indicating that proper grouping has been made.

TABLE $V$.

TOTAL VARIANCE EXPLAINED

\begin{tabular}{|l|c|c|c|c|c|c|c|c|c|}
\hline $\begin{array}{c}\text { C } \\
\text { o } \\
\text { m }\end{array}$ & \multicolumn{3}{|c|}{ Initial Eigenvalues } & \multicolumn{3}{|c|}{$\begin{array}{c}\text { Extraction Sums of } \\
\text { Squared Loadings }\end{array}$} & \multicolumn{3}{|c|}{$\begin{array}{c}\text { Rotation Sums of } \\
\text { Squared Loadings }\end{array}$} \\
\hline & $\begin{array}{c}\text { Tot } \\
\text { al }\end{array}$ & $\begin{array}{c}\text { \% of } \\
\text { Vari } \\
\text { ance }\end{array}$ & $\begin{array}{c}\text { Cum } \\
\text { ulati } \\
\text { ve \% }\end{array}$ & $\begin{array}{c}\text { Tot } \\
\text { al }\end{array}$ & $\begin{array}{c}\text { \% of } \\
\text { Vari } \\
\text { ance }\end{array}$ & $\begin{array}{c}\text { Cum } \\
\text { ulati } \\
\text { ve \% }\end{array}$ & $\begin{array}{c}\text { Tot } \\
\text { al }\end{array}$ & $\begin{array}{c}\text { \% of } \\
\text { Vari } \\
\text { ance }\end{array}$ & $\begin{array}{c}\text { Cumu } \\
\text { lative } \\
\text { \% }\end{array}$ \\
\hline 1 & 9.14 & 38.10 & 38.10 & 9.14 & 38.10 & 38.10 & 5.20 & 21.67 & 21.675 \\
\hline 2 & 2.00 & 8.340 & 46.44 & 2.00 & 8.340 & 46.44 & 4.25 & 17.72 & 39.399 \\
\hline 3 & 1.55 & 6.463 & 52.90 & 1.55 & 6.463 & 52.90 & 2.36 & 9.835 & 49.234 \\
\hline 4 & 1.39 & 5.814 & 58.72 & 1.39 & 5.814 & 58.72 & 2.03 & 8.461 & 57.695 \\
\hline 5 & 1.19 & 4.994 & 63.71 & 1.19 & 4.994 & 63.71 & 1.44 & 6.020 & 63.715 \\
\hline 6 & .809 & 3.371 & 67.08 & & & & & & \\
\hline 7 & .798 & 3.325 & 70.41 & & & & & & \\
\hline 8 & .703 & 2.929 & 73.34 & & & & & & \\
\hline 9 & .663 & 2.762 & 76.10 & & & & & & \\
\hline 10 & .644 & 2.684 & 78.78 & & & & & & \\
\hline 11 & .565 & 2.356 & 81.14 & & & & & & \\
\hline 12 & .493 & 2.056 & 83.19 & & & & & & \\
\hline 13 & .460 & 1.916 & 85.11 & & & & & & \\
\hline 14 & .442 & 1.840 & 86.95 & & & & & & \\
\hline 15 & .431 & 1.795 & 88.75 & & & & & & \\
\hline 16 & .422 & 1.759 & 90.50 & & & & & & \\
\hline 17 & .363 & 1.511 & 92.02 & & & & & & \\
\hline 18 & .356 & 1.482 & 93.50 & & & & & & \\
\hline 19 & .314 & 1.309 & 94.81 & & & & & & \\
\hline 20 & .296 & 1.234 & 96.04 & & & & & & \\
\hline 21 & .273 & 1.139 & 97.18 & & & & & & \\
\hline 22 & .262 & 1.091 & 98.27 & & & & & & \\
\hline 23 & .224 & .932 & 99.20 & & & & & & \\
\hline 24 & .190 & .792 & 100.0 & & & & & & \\
\hline Extraction Method: Principal Component Analysis. & & & \\
\hline
\end{tabular}

Factor 3 has 4 variables represents efficiency of erecruitment (Fast, accessible, cost effective, trustworthy). All these variables satisfactorily can explain more than 54\% as the factor loadings are above 0.54 . Factor 4 contains two variables reflects capability to use e-recruitment (capability to use and resource available to access internet). Factor 5 contains two variables which reflects the connectivity element (trouble in internet connection and the ability to compare vacancies of national and international level). Both these variables explain $77 \%$ and $57 \%$ respectively. This also indicates that the variables are satisfactory in explaining the factor. 
Proc. of the Eighth International Conference On Advances in Economics, Management and Social Study - EMS 2018 Copyright $(\subseteq$ Institute of Research Engineers and Doctors. All rights reserved.

ISBN no.978-1-63248-146-7 doi: 10.15224/ 978-1-63248-146-7-16

TABLE VI. TOTAL VARIANCE EXPLAINED

\begin{tabular}{|c|c|c|c|c|c|}
\hline & 1 & 2 & 3 & 4 & 5 \\
\hline $\begin{array}{llll}\begin{array}{l}\text { Positive attitude towards using } \\
\text { recruitment technology. }\end{array} & & \\
\text { recloge }\end{array}$ & .784 & & & & \\
\hline Recommend e- technology to my friends. & .767 & & & & \\
\hline $\begin{array}{l}\text { Compared with the traditional recruitment e- } \\
\text { recruitment technology is better. }\end{array}$ & .754 & & & & \\
\hline $\begin{array}{l}\text { Intention to use e-recruitment for vacancy } \\
\text { search in future. }\end{array}$ & .737 & & & & \\
\hline $\begin{array}{l}\text { Willing to use e-recruitment for vacancy } \\
\text { search. }\end{array}$ & 716 & & & & \\
\hline E-recruitment use for job search is high. & .661 & & & & \\
\hline Using e-recruitment sites are interesting. & .648 & & & & \\
\hline $\begin{array}{l}\text { The actual process of using e- recruitment } \\
\text { sites is pleasant. }\end{array}$ & .627 & & & & \\
\hline Saves time to submit resume & .522 & & & & \\
\hline $\begin{array}{l}\text { The e-recruitment sites provide information } \\
\text { such as faqs. }\end{array}$ & & .776 & & & \\
\hline $\begin{array}{l}\text { The e-recruitment sites provide feedback } \\
\text { service. }\end{array}$ & & .759 & & & \\
\hline $\begin{array}{l}\text { The e-recruitment sites provide all the } \\
\text { information required to apply for a job. }\end{array}$ & & .733 & & & \\
\hline It is easy to complete e-application. & & .715 & & & \\
\hline Using e- recruitment sites was easy & & .652 & & & \\
\hline $\begin{array}{l}\text { Interacting with online application process } \\
\text { was clear and understandable E-recruitment } \\
\text { sites and their application process did not } \\
\text { require a lot of mental effort. }\end{array}$ & & .643 & & & \\
\hline $\begin{array}{l}\text { It was easy to become skillful using e- } \\
\text { recruitment sites. }\end{array}$ & & .590 & & & \\
\hline $\begin{array}{l}\text { E-recruitment is the fastest mode to apply } \\
\text { for jobs. }\end{array}$ & & & .756 & & \\
\hline $\begin{array}{l}\text { Applying through job portal and social } \\
\text { network site is more accessible to the } \\
\text { candidate. }\end{array}$ & & & .678 & & \\
\hline $\begin{array}{l}\text { Applying for the jobs online is cost saving } \\
\text { activity for the prospective employees. }\end{array}$ & & & .625 & & \\
\hline $\begin{array}{l}\text { Online recruitment site can be trusted with } \\
\text { professional information. }\end{array}$ & & & .545 & & \\
\hline Capability to use the e-recruitment. & & & & 814 & \\
\hline $\begin{array}{l}\text { Possession of essential resources to support } \\
\text { to access the internet. }\end{array}$ & & & & .736 & \\
\hline Trouble in the internet connection & & & & & .775 \\
\hline $\begin{array}{l}\text { Using e-recruitment sites enable me to } \\
\text { compare between different vacancies in my } \\
\text { country and other countries. }\end{array}$ & & & & & .572 \\
\hline \multirow{2}{*}{\multicolumn{6}{|c|}{$\begin{array}{l}\text { Extraction Method: Principal Component Analysis. } \\
\text { Rotation Method: Varimax with Kaiser Normalization. } \\
\text { a. Rotation converged in } 7 \text { iterations. }\end{array}$}} \\
\hline & & & & & \\
\hline
\end{tabular}

\section{v. Findings of Study}

On completing the analysis the study it can be found that the most influential factor that persuade job seekers to use erecruitment is the attitude towards e-recruitment followed by usefulness of the content. To enhance the positive attitude of the job seekers awareness about the advantages of erecruitment can influence the use online recruitment. The organizations can focus more on designing effective interface to motivate the job seekers to apply online. The next factor that organizations need to pay attention is the efficiency aspect. Here they need to concentrate on designing the recruitment process which is faster, cost effective, accessible and secured. The 4th factor of element represents capability to use e-recruitment. Here the ability to access and use of internet will increase the use of erecruitment. The 5th factor that needs attention is the connectivity which depends on the availability of internet service in the country. As Bangladesh is in the era of digitalization, the government is supporting the development of IT sector. These initiative will motivate the job seekers to use e-recruitment more.

\section{vi. Conclusions}

Despite the contribution this paper makes there exists some limitations which cannot be overlooked. First, due to unavailability of sampling frame probability sampling could not be used. Next the sample size of 234 may not fully represent the population. Moreover due to budget and time constraints the scope was limited to the major city like Dhaka. This does not represent the population of the entire nation.

The scope of this paper was only to conduct exploratory factor analysis on intention of job seekers regarding the use of e-recruitment in Dhaka city. The next step ahead could be conducting a confirmatory factor analysis showing interrelationship of variables or preparing a regression equation model that could explain how much each of these elements effect the dependent variable. Moreover by conducting this study outside Dhaka city, the researcher can open some new avenues for the organization that operate outside Dhaka.

\section{References}

[1] The Australian HR Institute (2017). Recruitment and Selection.

[2] S.L, L. (2016). E - RECRUITMENT: A BOOM TO THE ORGANIZATIONS IN THE COMPETITIVE WORLD. IOSR Journal of Business and Management (IOSR - JBM), pp.25-28.

[3] Alsultanny, Y. and F. Alotaibi, M. (2015). Evaluating the Factors Affecting on Intension to Use of E-Recruitment. American Journal of Information Science and Computer Engineering, 1(5), pp.324-331.

[4] Ahlawat, D.R. (2016). E - RECRUITMENT: TRANSFORMING TRENDS OF RECRUITMENT IN HUMAN RESOURCE MANAGEMENT. Global Journal of Engineering $S$ cience and $R$ esearch $M$ anagement, 2(265).

[5] Pavon, F., \& Brown, I. (2010). Factors influencing the adoption of the World Wide Web for job-seeking in South Africa. SA Journal Of Information Management, 12(1).

[6] Parry, E., \& Wilson, H. (2009). Factors influencing the adoption of online recruitment. Personnel Review, 38(6), 655-673.

[7] Karim, M., Miah, M. and Khatun, A. (2018). E-Recruitment in Practice: A Study on Jobseekers' Perception in Bangladesh. Global Disclosure of Economics and Busines, 4(1), p.34.

About Author (s):

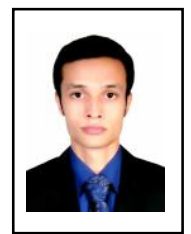

SK. Tasthekur Hossain Kowshik completed his Bachelor in Business Administration from American International University- Bangladesh with major in Human Resource Management and Marketing in 2017. He has worked as a research assistant with the different supervisor. His preferred research areas include human resource management, consumer behavior, and service marketing. Currently, he is working in flydubai as a ground service officer. 

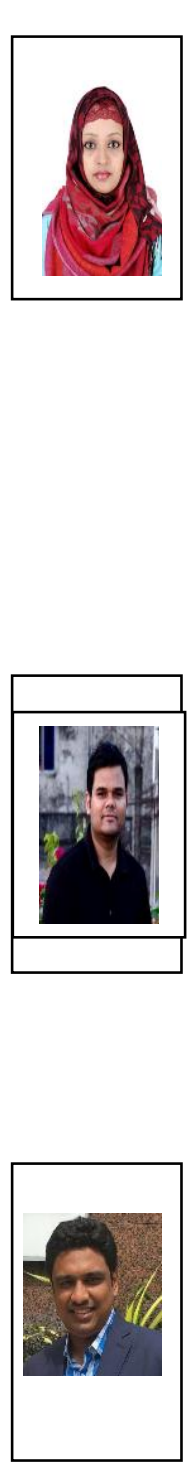

Samia Shabnaz is a Senior Assistant Professor in the Department of Management, American International University-Bangladesh (AIUB). She received Masters in Business Administration from AIUB, in 2008. She has more than 8 years of experience in teaching several areas of Human Resource Management and her research interest includes microcredit impact assessment, entrepreneurship development initiative, and human resource development. She is currently perusing her M-Phil in Bangladesh University of Professional (BUP).

Stanley Sumon Rodrick is serving as an Assistant Professor in the Department of Marketing at the American International University-Bangladesh (AIUB) since January 2010. His research interest includes brand development, rural marketing, agro-based product marketing, consumer behavior, and digital marketing impact on the consumer segments.

Hamidul Islam is serving as an Assistant Professor in the Dept. of Marketing at the American International UniversityBangladesh (AIUB) since May 2009. He started his corporate career as a Sales and Distribution Executive at Kallol Group of Companies Ltd. Impact of IMC, Branding, Digital Marketing on Consumer Behavior are his major areas as research interest. 